\title{
Pathogenicity of Beauveria bassiana strains against Drosophila suzukii (Diptera:
}

\section{Drosophilidae)}

\author{
Patogenicidade de linhagens de Beauveria bassiana contra Drosophila suzukii (Diptera:
}

Drosophilidae)

Patogenicidad de cepas de Beauveria bassiana contra Drosophila suzukii (Diptera: Drosophilidae)

Received: 01/14/2022 | Reviewed: 01/27/2022 | Accept: 01/28/2022 | Published: 01/29/2022

Jason Lee Furuie

ORCID: https://orcid.org/0000-0002-9138-5502

Federal University of Paraná, Brazil E-mail: jason.furuie@gmail.com

Andressa Katiski da Costa Stuart

ORCID: https://orcid.org/0000-0002-9474-7572

Federal University of Paraná, Brazil

E-mail: andressa.katiski@gmail.com

Franciele Baja

ORCID: https://orcid.org/0000-0003-1609-0680 Federal University of Paraná, Brazil E-mail: francibajinha@gmail.com

Morgana Ferreira Voidaleski

ORCID: https://orcid.org/0000-0003-2751-352X Federal University of Paraná, Brazil

E-mail: morganavoidaleski@gmail.com

Maria Aparecida Cassilha Zawadneak ORCID: https://orcid.org/0000-0003-0004-5623 Federal University of Paraná, Brazil E-mail: cidazawadneak@gmail.com

Ida Chapaval Pimentel

ORCID: https://orcid.org/0000-0002-1840-1748 Federal University of Paraná, Brazil E-mail: idinhaufpr@gmail.com

\begin{abstract}
The biological control (BC) is an efficient tool in helping to reduce pests in crops of economic interest. In addition to the efficiency, there are advantages in using biological control agents, such as human safety and other non-target organisms and decreasing pesticide residues. The general aim of this work was to evaluate in vitro the pathogenicity power of fifteen Beauveria bassiana strains aiming the biological control of Drosophila suzukii (Matsumura, 1931). Successful infection of entomopathogenic fungi depends primarily on the adherence and penetration ability of a fungus to the host integuments. In addition, scanning electron microscopy was realized. To verify the spore adherence after the spraying tests, insects were collected throughout the bioassays in order to confirm spore evolution on the insect cuticle. In this work, D. suzukii adults were not susceptible to the aqueous suspensions of conidia at concentrations of $10^{8}$ spores $\mathrm{mL}^{-1}$ of these strains. There wasn't death confirmed by fungus extrusion after maintenance in humid chamber.
\end{abstract}

Keywords: Spotted-wing drosophila; Microbial control; Entomopathogenic fungi.

\section{Resumo}

O controle biológico é uma ferramenta eficiente para ajudar a reduzir pragas em culturas de interesse econômico. Além da eficácia, as vantagens no uso destes agentes, a segurança para humanos e outros organismos não-alvo e a diminuição de resíduos de pesticidas são extremamente relevantes. O objetivo geral deste estudo foi avaliar in vitro a patogenicidade de 15 linhagens de Beauveria bassiana, anteriormente testadas contra outra praga de interesse, visando o controle biológico de Drosophila suzukii (Matsumura, 1931). Para uma infecção no hospedeiro bem-sucedida, os fungos entomopatogênicos dependem principalmente da aderência e capacidade de penetração nos tegumentos do hospedeiro. Sendo assim, foi realizada também uma microscopia eletrônica de varredura. Para verificar se houve aderência dos esporos após os testes de pulverização, foram coletados insetos durante os bioensaios, com o objetivo de confirmar a evolução dos esporos na cutícula dos insetos. Neste trabalho, adultos de D. suzukii não foram suscetíveis às suspensões aquosas de esporos em concentrações de $10^{8}$ esporos- $\mathrm{mL}^{-1}$ de nenhuma das linhagens 
testadas, uma vez que não houve morte confirmada por extrusão de fungos após manutenção dos insetos em câmara úmida.

Palavras-chave: Drosófila-da-asa-manchada; Controle microbiano; Fungo entomopatogênico.

\section{Resumen}

El control biológico es una herramienta eficaz para ayudar a reducir las plagas en los cultivos de interés económico. Además de la eficacia, el uso de estos agentes presenta ventajas, como la seguridad para los seres humanos y otros organismos y la reducción de los residuos de plaguicidas. El objetivo general de este estudio fue evaluar in vitro la patogenicidad de 15 cepas de Beauveria bassiana para el control biológico de Drosophila suzukii (Matsumura, 1931). Además, se sabe que el éxito de la infección de los hongos entomopatógenos depende principalmente de la adherencia y la capacidad de penetración de un hongo en los tegumentos del huésped y, por lo tanto, se realizó una microscopía electrónica. Para comprobar la adherencia de las esporas después de las pruebas de pulverización, se recogieron insectos a lo largo de los bioensayos para confirmar la evolución de las esporas en la cutícula del insecto.. En este trabajo, los adultos de $D$. suzukii no fueron susceptibles a las suspensiones acuosas de esporas en concentraciones de $10^{8}$ esporas- $\mathrm{mL}^{-1}$ de estas cepas. No se confirmó la muerte por extrusión de hongos en la cámara húmeda.

Palabras clave: Drosophila de alas manchadas; Control microbiano; Hongos entomopatógenos.

\section{Introduction}

The spotted-wing drosophila (SWD), Drosophila suzukii (Matsumura, 1931) is a polyphagous insect capable of reproducing in more than 60 cultivated and wild plants (Lee, et al., 2015). The first report of SDW was made by Matsumura in Japan in 1931. Since then, D. suzukii has been reported causing damage to different fruits in countries of Europe, and North and South America. In Brazil, it was found in municipalities of Rio Grande do Sul, Santa Catarina (Deprá, et al., 2014) and Paraná (Geisler, et al., 2014) states. The rapid spread of this pest is suspected to have been caused by passive diffusion of the fruits through exportation of egg-contaminated fruits.

It is a species known to cause direct damage to small fragile integument fruits such as blackberry, cherry, raspberry, blueberry, and strawberry. Such damage is due to the perforations made by females on the fruit surface, during oviposition (Bernardi, et al., 2015). Oviposition in mature fruits is possible only by the presence of a double serrated and narrow ovipositor in females, a distinguishing feature of most other drosophilids. The identification of males can be done by visualizing the presence of dark spots on the final part of the wings and a comb line with prominences in the first and second tarsal segments of the first pair of legs (Calabria, et al., 2012). Females begin ovipositing from the second day after emergence and can oviposit, on average, 7 to 16 eggs per day, being able to oviposit up to 600 eggs throughout their life cycle. The larvae hatch within 48 hours of oviposition and the reaches their last instar within 7 days. The pupal period usually occurs within the fruit and may eventually occur in the soil and takes around 7 days (Emiljanowicz, et al., 2014). Spotted-wing drosophila can withstand large variations in temperature, but are more suited to mild temperatures, around 20 to $25^{\circ} \mathrm{C}$, preferably with high humidity. This climate scenario is easily found in temperate regions in Brazil and elsewhere in South America. The damage caused by SWD is high due to the presence of eggs and larvae in ripe fruits and their control is hampered by the behavior of larvae, which penetrate the fruit to feed, which facilitates the entry of harmful microorganisms to the fruit, responsible for the rapid rotting of the fruit and consequent loss of commercial viability.

Among the different fruits attacked by $D$. suzukii are strawberry fruits, a group of plant species belonging to the family Rosaceae, genus Fragaria L., which includes the species Fragaria $\mathrm{x}$ ananassa. Strawberry is a pseudo-fruit of great economic importance worldwide (Amil-Ruiz, et al., 2011) especially in the United States and Europe and with significant growth in its production in Latin America (Coelho Junior, 2016). Strawberry is the most important among the small fruits, characterized by being a culture with fast economic return. However, it is a culture that requires special care for its production. Its production is characterized by intensive use of pesticides, which makes this a motivation of researchers in the search for less aggressive, more natural alternatives, without compromising the soil or the fruit itself (Coelho Junior, 2016).

Given the damaging scenario caused using agrochemicals, strategies that implement Integrated Pest Management 
(IPM) should be explored (Corassa, et al., 2022). IPM consists of several control strategies, and BC is one of them. BC is defined as the use of one organism to reduce the population density of another organism and has been shown to be effective in controlling pests of various crops (Alvin, Miller \& Neilan, 2014). In addition, BC is considered the only effective and permanent solution capable of reducing the damage BC predators, parasitoids, and microorganisms such as bacteria, viruses and fungi are employed. Among the fungi used in this control strategy are the entomopathogenic fungi (EF) (Hajek \& Delalibera Jr, 2010).

The use of EF has been shown to be very effective in controlling pests and phytopathogens, raising interest in development of biopesticides (Van Lenteren, et al., 2018). In addition to its effectiveness in biocontrol, it promotes a decrease in the application of agrochemicals, reducing damage to the environment and the health of workers and consumers (Grupta \& Dikshit, 2010). Mycoinseticides may play an important role in pest regulation by developing epizootic diseases that cause the rapid reduction of host populations (Amatuzzi, et al., 2018). These fungi met the pest, spores penetrate the body cavity, with the fungus developing and internally colonizing the insect's body and causing its death (Pell, et al., 2010). Entomopathogenic fungi are common in terrestrial environments, acting to reduce the population of pest insects, mainly through contact (Hajek \& Delalibera, 2010). Among the EF studied, efforts have been applied mainly to species belonging to the order Hypocreales, as they have a wide range of hosts and facilities for their mass production (Butt, Jackson \& Magan, 2001). Among these potential fungi are the genera Beauveria, Isaria and Metarhizium that could control a large variety of insects added to their cosmopolitan distribution (Roberts \& Ieger, 2004). About $80 \%$ of commercially available insect control products are based on the genera Metarhizium and Beauveria (Faria \& Wraight, 2007; Amattuzi, et al., 2018).

Although promising, there are no records of bioinsecticides formulated from fungi to control SWD in Brazil (MAPA, 2019). In this context, BC is a tool to be considered for developing strategies in the composition of an IPM for SWD. Thus, the general aim of this study was to evaluate the in vitro pathogenicity power of each isolate aiming the biological control of $D$. suzukii. For this, microbial agents were tested for pathogenicity against adult individuals of SWD.

\section{Methodology}

\subsection{Biological material}

\subsubsection{D. suzukii breeding}

The initial individuals of SWD came from larval collections of strawberry (Fragaria vesca) fruits in Curitiba, PR (25.447052, -49.233127). Strawberries with signs of oviposition by drosophilids were collected and desiccated in the laboratory and the larvae found were kept until adulthood, to be morphologically identified. For identification, adult specimens were observed with ether under stereoscopic microscope (40x) in the laboratory. The insects were kept on an artificial diet, which consisted of brewer yeast $(40 \mathrm{~g} / \mathrm{L})$, corn meal $(60 \mathrm{~g} / \mathrm{L})$, dextrose $(100 \mathrm{~g} / \mathrm{L})$, propionic acid $(3 \mathrm{~mL} / \mathrm{L})$, methylparaben $(7 \mathrm{~mL} / \mathrm{L})$, and agar $(8 \mathrm{~g} / \mathrm{L})$ and stored under controlled conditions $\left(25 \pm 1^{\circ} \mathrm{C}, \mathrm{RH} \pm 60 \%\right.$ and $12 \mathrm{~h}$ photoperiod) in a room for breeding insects, located at Professor Ângelo Moreira da Costa Lima Laboratory, Biological Sciences Sector, Federal University of Paraná.

\subsubsection{Entomopathogenic fungi}

The fifteen B. bassiana strains (CMRP4474-CMRP4488) used in this study were from the Microbiological Collection of the Paranaense Network - TAXonline (CMRP), Federal University of Paraná (Curitiba, Brazil) (http://splink.org.br), which were chosen by their pathogenicity against another agricultural pest (Furuie, et al., 2022). 


\subsection{Pathogenicity assay against $D$. suzukii}

\subsubsection{Inoculum preparation}

Fungal preparation single-spore fungal cultures of each strain were cultured on Sabouraud Dextrose Agar (SDA) in Petri dishes and incubated for 14 days at $28^{\circ} \mathrm{C}$. After this period, conidia from each strain were harvested using a sterile steel spatula under sterile flow conditions to scrape them into glass tubes with $15 \mathrm{~mL}$ of $0.85 \%$ saline solution containing $0.01 \%$

Tween ${ }^{\circledR} 80$. Conidial suspensions of each strain were vortexed for $5 \mathrm{~min}$ at $120 \mathrm{rpm}$ and then filtered, using sterile gauze, into new glass tubes. Suspensions were prepared independently for each assay and concentrations were adjusted by serial dilution in an aqueous $0.3 \%$ Tween ${ }^{\circledR} 80$ solution. Spore suspensions were used immediately after preparation and concentrations were adjusted using a hemocytometer. Spore viability was then determined using an optical microscope (100x magnification) by visualization of 250 spores; spores that presented germinative tube growth were considered as viable.

\subsubsection{Spraying assay}

This assay was conducted to evaluate the direct contact by the conidia. Each treatment was conducted with four replications. Twenty SWD adults were transferred to each bottle, so that each bottle was considered a replication, for a total of 80 adults tested per treatment. A Sagyma SW776 airbrush (101b.pol ${ }^{-1}$ ) was used to spray $1 \mathrm{~mL}$ of a spore suspension at a concentration of $10^{8}$ conidia. $\mathrm{mL}^{-1}$ and Tween ${ }^{\circledR} 80$ at $0.3 \%$ over the individuals. The control treatment received $1 \mathrm{~mL}$ of sterile distilled water with $0.3 \%(\mathrm{v} / \mathrm{v})$ Tween ${ }^{\circledR} 80$. After spraying, all the bottles were kept under controlled conditions. Mortality was assessed until 7 days. Moribund individuals or those that did not respond to touch with a paintbrush were considered dead. These specimens were transferred to Petri dishes with moistened filter paper until fungal extrusion to check for postmortem sporulation. The bioassay was carried out for 4 weeks, with 4 strains tested per week. The experimental design was completely randomized.

\subsubsection{Ingestion blastospore inoculation assay}

Each treatment was conducted with four replications. Twenty adults of D. suzukii were transferred to each bottle, so that each bottle was considered a replication, for a total of 80 adults tested per treatment. Were tested only 2 strains in this assay, as a screening assay: CMRP4474 and CMRP4475. The inoculum preparation was performed as described in item 2.2.1 and inoculated in liquid medium to induce the formation of the structures of interest, according to Pham et al., 2009. One $\mathrm{mL}$ of the medium after 4 days growing shaking at $25^{\circ} \mathrm{C}$ was diluted in $9 \mathrm{~mL}$ distilled water and adjusted using a hemocytometer. Blastospore suspensions at concentration of $10^{7}$ blastospore $\mathrm{mL}^{-1}$ of both strains were dispensed directly on the artificial diet and after this, 20 D. suzukii adults who spent 4 hours without eating were transferred and kept under controlled conditions for one week. The control treatment received $1 \mathrm{~mL}$ of sterile distilled water with $0.3 \%(\mathrm{v} / \mathrm{v})$ Tween ${ }^{\circledR} 80$. Mortality was verified only at the last day of the experiment. Postmortem sporulation was checked, and the experimental design was completely randomized.

\subsection{Scanning electron microscopy}

Insect collections to fixation were performed every $6 \mathrm{~h}$ for 7 days after spore suspension spraying. Each one was sacrificed by freezing $\left(-20^{\circ} \mathrm{C}\right)$ and fixed in a $3 \%(\mathrm{v} / \mathrm{v})$ glutaraldehyde solution in $0.1 \mathrm{M}$ sodium cacodylate buffer for $24 \mathrm{~h}$ at $4{ }^{\circ} \mathrm{C}$ and subsequently dehydrated in an upward series (30 to 100\%, for $1 \mathrm{~h}$ at each dilution) of ethyl alcohol (Jeffs, et al., 1999). The critical point of the samples was made and after being dried, mounted on carbon tape stubs and sprayed with gold (SCD 030 metallizer). Observation was performed with the TESCAN SEE 3 LMU Scanning Electron Microscope. 


\subsection{Statistical analysis}

Mortality data of pathogenicity tests were corrected for control survival (Abbott, 1925). Subsequently data were tested for normality (Shapiro \& Wilk, 1965). Then they were submitted to analysis of variance (two-way ANOVA) and generalized linear models (Nelder \& Baker, 1972). When necessary, means were compared with the Tukey test with 5\% of probability. Survival analyses were analyzed for 8 days and were significant after 3 days $(\mathrm{p}<0,05)$.

\section{Results}

\subsection{Pathogenicity assay against $D$. suzukii}

\subsubsection{Spraying assay}

It was verified in the direct contact bioassay that the lowest average survival rate was obtained only on the last day of evaluation and that it reached only $60 \%$ for CMRP4475. That is, of the 80 individuals tested with the CMRP4475 strain, less than half (32) died. The overall survival average was $77.86 \%$ among all strains tested on the eighth day of analysis, which means a high survival value of the insect tested against the fifteen strains and, consequently, makes it impossible to choose these Beauveria strains to D. suzukii control (Figure 1). From the total of 1520 adult individuals used in this bioassay, 58 died in the control and 262 died in the different treatments, which were individualized in sterile microtubes, showed no fungal extrusion, which doesn't confirm the causal agent of death by the fungus inoculated via direct contact.

Figure 1 - Survival rate from each strain until 7 days of spraying bioassay on adults (1-4 represent a week with 4 different strains tested).

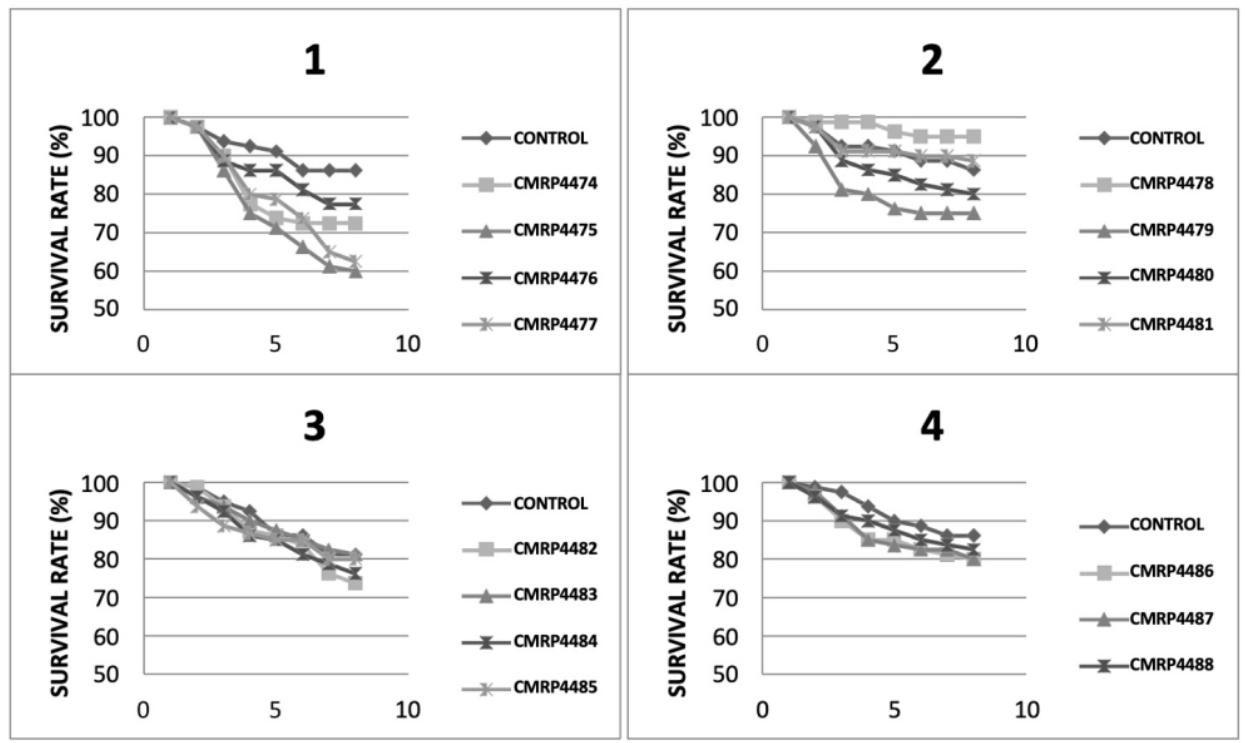

Source: Authors.

\subsection{Ingestion blastospores inoculation assay}

After growth of suspension in liquid medium and counting in hemocytometer, suspensions were used in concentrations of $1.11 \times 10^{8}$ for CMRP4474 and $1.04 \times 10^{8}$ for CMRP4475. Survival rate was checked only on the eighth day to analyze whether the method generated different values than the direct contact bioassay, but for CMRP4474 strain the survival rate was $87.25 \%$ and for CMRP4475 strain $84.75 \%$ versus $96.5 \%$ survival in the control group. Of the 240 adult individuals used in this bioassay, 14 died in the control and 48 died in both treatments, which were individualized in sterile microtubes and 
kept in a humid chamber, showed no fungal extrusion, which does not confirm the causal agent of death by the fungus inoculated with the blastospores suspensions on the artificial diet.

\subsection{Scanning electron microscopy}

Since it was not possible to confirm the causal agent of the death of adult individuals by fungal extrusion in both bioassays, the SEM technique was performed to verify the presence or absence of germinated spores and in the process of host cuticle colonization. Although the number of spores was large, there was no cellular differentiation between the analyzed period (5 days), and they remained unchanged from the beginning to the end of the evaluated period (Figure 2). It can justify the low mortality observed in the performed bioassays and the non-fungal extrusion of any specimen, since it was possible to prove by the SEM technique that the spores do not adhere to the Drosophila cuticle to colonize.

Figure 2 - A) Spores under the D. suzukii abdomen cuticule without adherence after 24 hours of inoculation. B) Spores under the $D$. suzukii cuticule without adherence after 3 days of inoculation. C) Spores under the D. suzukii paw without germination after 5 days of inoculation. The red arrows indicate the B. bassiana spores. Images by TESCAN SEE 3 LMU Scanning Electron Microscope.

Beauveria sp. spores

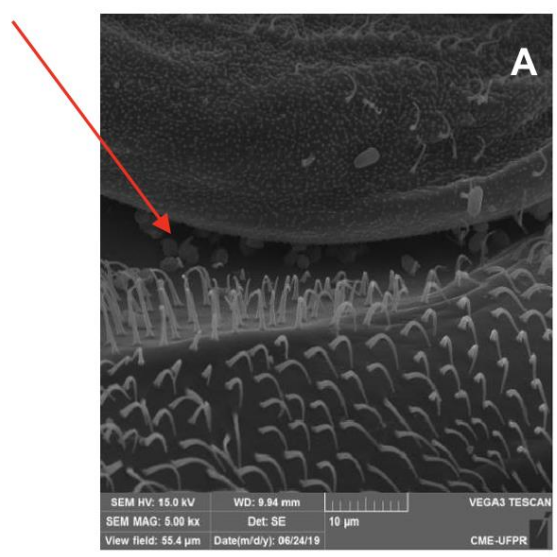

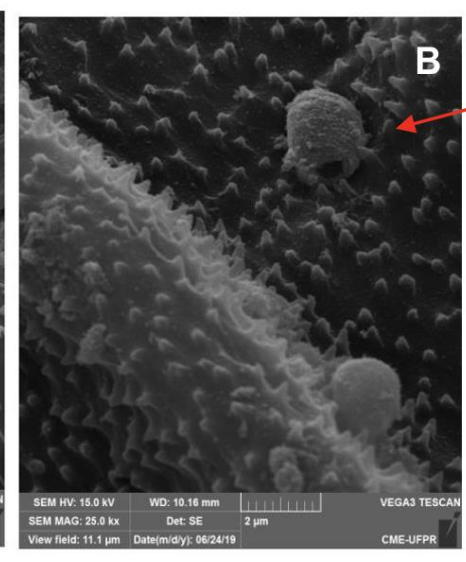

Source: Authors.
Beauveria sp. spores

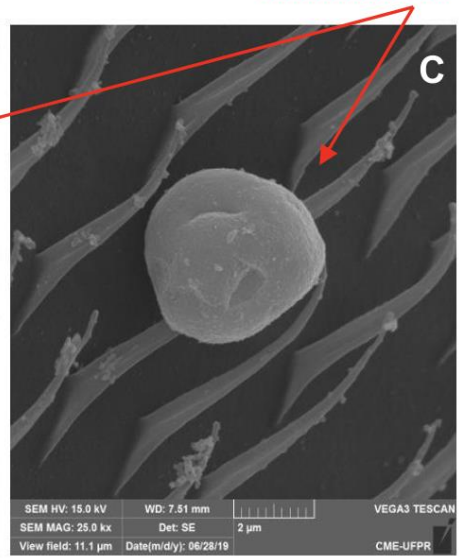

\section{Discussion}

The entomopathogenic action needs to be rapid, to avoid oviposition and direct and indirect fruit damage caused by D. suzukii adults. The life cycle of EF on the insect cuticle begins with spore germination and penetration followed by proliferation of fungal hyphae, which ultimately desiccate the hosts, and continues with the production of infective spores that can insert themselves immediately into the cuticle to repeat the cycle (Al-Aidoors \& Roberts, 1978). It is possible to see that in some studies that mention the pathogenicity of EF against $D$. suzukii, it is not clear if only the deaths confirmed by extrusion after disinfection of the dead insect are counted. Gutierrez-Palomares, et al., 2021, reported that the mortality caused by $B$. bassiana occurred after several days (15.3 days), allowing the infected flies to continue laying eggs and damaging fruits. Woltz, et al., 2015 concluded that the higher fly mortality on the first day of monitoring is likely due to stress from being handled, as this did not vary between the treatment and control.

The best value (60\%) of survival on adults' assays was with CMRP4475, representing just 32 of 80 total individuals submitted by the test at the last evaluated day, but not showing any fungal extrusion to death causal confirm. This data 
represents a non-effective strain to use in BC once the D. suzukii female can oviposit 6 eggs per day under the fruits.

About $80 \%$ of commercially available insect control products are based on the genera Metarhizium and Beauveria (Faria et al., 2007), showing the relevance of these genera in studies about virulence in different insects.

Expression of a variety of hydrolytic enzymes, e.g., proteases, chitinases, and lipases, and other factors, promote germination and growth of the fungus across the surface of the host, and subsequent penetration of cuticular layers (Xiao, et al., 2012). During this process the fungus produces any number of specialized infection structures that can include penetration pegs and/or appressoria, which enable the growing hyphae to penetrate the host integument. It is essentially in the later stages of this process that the pathogen encounters the host immune system. The insect cuticle itself is a highly heterogeneous structure that can vary greatly in composition even during the various life-stages of a particular insect (Ortiz-Urquiza et al.,2013).

Cuticular lipids, however, can also promote or inhibit fungal attachment to cuticle. Such attachment can be affected by nutritional requirements and can be enhanced via formulation that can result in increased efficacy of the fungal agents against target insects (Akbar, et al., 2004) which may explain the negative results of the tested strains in this study. In the blastospore suspension assay, there was no observed efficacy and survival rates were even higher than in the direct contact tests, where CMRP4474 showed a rate of $87.25 \%$ and CMRP4475 $84.75 \%$, compared to $72.5 \%$ and $60 \%$ respectively in the direct contact test.

Buchon, et al., 2013 shows that D. melanogaster has emerged as a powerful model in which to investigate interactions between pathogens and gut-associated microorganisms in the intestinal tract, that could explain the ineffectiveness of this drosophila inoculation method, as well as presenting an immune system with characteristics capable of identifying pathogenic bacteria, which may probably explain the ineffectiveness of any EF in drosophilids.

Finally, considerations of the interactions between entomopathogenic fungi and the cuticle surface can elicit specific behavioral responses (often in conjunction with chemical/proteinaceous defenses and/or the actions/products of symbiotic bacteria) in the insect meant to limit the ability of the pathogen to parasitize the host. For social insects, nestmate grooming is a well-recognized mechanism for minimizing potentially harmful microbes, and for other insects self-grooming may likely play a similar role (Tragust, et al., 2013).

Although these fifteen strains did not show potential pathogenicity in this study, new isolates should be obtained and tested with the same objective. Our results reinforce that not every isolate of the genus Beauveria has virulence against more than one pest. Some isolates may have more virulence against certain insect groups or may not have virulence, such as the isolates of this study that were not effective in controlling D. suzukii but showed high pathogenicity against Lema bilineata (Furuie, et al., 2022). New studies with new isolates are important to search more virulent fungi in pest control, such as the study by Amattuzi, et al., 2018 which isolated endophytic fungi and tested their virulence against D. fovealis. Insects have evolved an array of defenses against microbes that are ubiquitous in the environments that they inhabit. These extend from the cuticle that can be reinforced with antimicrobial compounds and secretions to behavioral adaptions (Buchon, et al., 2013).

\section{Final Considerations}

Finally, this study showed that even though the EF strains tested in this study were pathogenic for other insects, they were not for SWD. In this case, these Beauveria strains could not cause pathogenicity and confirmed death to SWD adults, showing that we need more study and more fungi isolations aiming the effective biological control of $D$. suzukii with EF.

\section{Acknowledgments}

We thank the CME-UFPR for the support on SEM images. 


\section{References}

Akbar, W., Lord, J. C., Nechols, J. R., Howard, R. W. (2004). Diatomaceous earth Increases the efficacy of Beauveria bassiana against Tribolium castaneum larvae and increases conidia attachment. J Econ Entomol, 97(2), 273-80.

Al-aidoors, K., Roberts, D. R. (1978). Mutants of Metarhizium anisopliae with increased virulence toward mosquito larvae. Genet. Cytol., 11, $211-219$.

Alvin, A., Miller, K. I., Neilan, B. A. (2014). Exploring the potential of endophytes from medical plants as sources of antimycobacterial compounds. Microbiol Research, 169(7), 486-95.

Amatuzzi, R. F., et al. (2018). Fungos endofíticos para o biocontrole de Duponchelia fovealis (Zeller) (Lepidoptera:Crambidae), Braz J Biol, 78(3), 429435 .

Alves, S. B., Pereira, R. M. (1998). Produção de fungos entomopatogênicos. In Controle microbiano de insetos, Alves, S.B. 2.ed. (Piracicaba: Fealq.), pp. 845-869.

Amil-ruiz, F., Blanco-portales, R., Muñoz-blanco, J., Caballero, J.L. (2011). The Strawberry plant defense mechanism: a molecular review. Plant and cell phisiology, 52(11), 1873-1903.

Bernardi, D., Botton, M., Nava, D. E., Zawadneak, M. A. C. (2015). Guia para identificação e monitoramento de pragas e seus inimigos naturais em morangueiro. (Brasília: Embrapa), pp. 23-29.

Buchón, N., Silverman, N., Cherry, S. (2014). Immunity in Drosophila melanogaster from microbial recognition to whole-organism physiology. Nature reviews: immunology, 14, 796-809.

Butt, T. M., Jackson, C., Magan, N. (2001). Introduction - fungal biological control agents: progress, problems, and potential. In fungi as biocontrol agents: progress, problems and potential. Cabi publishing (New York, USA, p.1-8).

Calabria, G., Maca, J., Bachli, G., Serra, L., Pascual, M. (2012). First records of the Potential pest species Drosophila suzukii (diptera: drosophilidae) in Europe. J appl entomol, 136, 139-147.

Coelho Junior, J. M. (2016). Strawberry cultivars: knowing to expand and reduce the environmental impacts. Geama, 2(2).

Corassa, J. N., Machiner, M., Valladao, D. M. S., Andrighetti, C. R., Weberling, J. B. (2002). Efeito de extrato etanólico de plantas sobre Spodopotera frugiperda (Lepdoptera: Noctuidae). Research, Society and Development, 11(2).

Deprá M., Poppe J. L., Schmitz H. J., De Toni D. C., Valente V. L. S. (2014). The first records of the invasive pest Drosophila suzukii in the South American continent. J. Pest sci., 87, 379-383.

Emiljanowicz, L. M., Ryan, G. D., Langille, A., Newman, J. (2014) Development, reproductive output, and population growth of the fruit by pest Drosophila suzukii (diptera: drosophilidae) on artificial diet. Journal of economic entomology, 107(4), 1392- 1398.

Faria, M. R., Wraight, S. (2007). Mycoinsecticides and mycoacaricide: a comprehensive list with worldwide coverage and international classification of formulation types. Biological control, 43(3), 237-256.

Furuie, J. L., Stuart, A. K. C., Voidaleski, M. F., Zawadneak, M. A. C., Pimentel, I. C. (2022). Isolation of Beauveria strains and their potential as control agents for Lema bilineata Germar (Coleoptera: Chrysomelidae). Insects, 13,93.

Geisler, F. C. S., Santos, J., Holdefer, D. R., Garcia, F. R. M. (2015). Primeiro registro de Drosophila suzukii (Matsumura,1931) Diptera:drosophilidae para o estado do Paraná, Brasil e de novos hospedeiros. Revista de ciências ambientais, 9(2), 125-129.

Gutierrez-Palomares, V. M., Paulino-Alonso, L., Gutierrez, J. Z., Alatorre-Rosas, R. (2021). Pathogenicity and virulence of Isaria javanica, Metarhizium anisopliae, and Beauveria bassiana strains for control of Drosophila suzukii (Matsumura). Southwestern Entomologist, 46(4), 853-860.

Grupta, S., Dikshit, A. K. (2010). Biopesticides: an ecofriendly approach for pest control. J biopestic., 3, 186-188.

Hajek, A.E., Delalibera JR., I. (2010). Fungal pathogens as classical biological control agents against arthropods. Biocontrol., 55(1), $147-158$.

Lee, J. C., Dreves, A. J., Cave, A. M., Kawai, S., Isaacs, R., Miller, J. C., Van Timmeren, S., Bruck, D. J. (2015). Infestation of wild and ornamental non crop fruits by Drosophila suzukii (Diptera: drosophilidae). Annals of the entomological society of America, 3, 1-13.

Myers, J. H., Cory, J.S. (2017). Biological control agents: invasive species or valuable solutions? Impact of biological invasions on ecosystem services., 191-202.

Ortiz-Urquiza, A., Keyhani, N.O. (2013). Action on the surface: entomopathogenic fungi versus the insect cuticle. Insects, 4(3), 357-374

Pell, J. K., Hannam, J. J., Steinkraus, J.J. (2010). Conservation biological control using fungal entomopathogens. Biological Control., 55, 187-198.

Pham, T. A., Kim, J. J., Kim, S. G., Kim, K. (2009). Production of blastospore of entomopathogenic Beauveria bassiana in a submerged batch culture. Mycobiology, 37(3), 218-224.

Poitevin, C. G., Porsani, M. V., Poltronieri, A.S., Zawadneak, M.A.C., Pimentel, I.C. (2018). Fungi isolated from insects in strawberry crops act as potential biological control agents of Duponchelia fovealis (Lepidoptera:Crambidae). Applied entomology and zoology.

Roberts, D. W., Ieger, R. S. (2004). Metharizium spp., cosmopolitan insect-pathogenic fungi: mycological aspects. Advances in applied microbiology., 54, $1-70$. 
Research, Society and Development, v. 11, n. 2, e41611225730, 2022

(CC BY 4.0) | ISSN 2525-3409 | DOI: http://dx.doi.org/10.33448/rsd-v11i2.25730

Tragust, S., Mitteregger, B., Barone, V., Konrad, M., Ugelvig, L.V., Cremers, S. (2013). Ants disinfect fungus-exposed brood by oral uptake and spread of their poison. Curr biol, 23(1), 76-82.

Tuininga, A. R., Miller, J.L., Morath, S.H., et al. (2009). isolation of entomopathogenic fungi from soils and ixodessacpularis (acari: ixodidae) ticks: prevalence and methods. J. Med. Entomol, 46(3), 557-567.

Van Lenteren, J. C., Bolckmans, K., Kohl, J., Ravensberg, W.J., Urbaneja, A. (2018). Biological control using invertebrates and microorganisms: plenty of new opportunitties. Biocontrol, 63, 39-59.

Xiao, G., Ying, S. H., Zheng, P., Wang, Z. L., Zhang, S., Xie, X. Q., Shang, Y.; ST Leger, R. J., Zhao, G. P., Wang, C., Feng, M.G. (2012). Genomic perspectives on the evolution of fungal entomopathogenicity in Beauveria bassiana, sci rep, 2, 483.

Woltz, J. M., Donahue, K. M., Bruck, D. J. Lee, J. C. (2015). Efficacy of commercially available predators, nematodes and fungal entomopathogens for augmentative control for Drosophila suzukii. Journal of Applied Entomology, 139(10), 759-770. 